\title{
Perlawanan Masyarakat Dusun Air Abik Dalam Menentang Perluasan Lahan Perkebunan Kelapa Sawit Dilihat Dari Teori Contentious Politics
}

\author{
M. Adha Al Kodri, S.Sos., M.A
}

\begin{abstract}
In the middle of district head's euphoria to float and move forward province of Bangka Belitung's island by brought in the palm oil investors conduce the new conflict of society, i.e agrarian conflicts. The presence of palm oil investors in the middle that in the beginning has been designed to give a profit for society, especially the societies around the oil palm plantation, but precisely harm the society a lot. For local society, indigenous forest is symbol of nature conservation and the place of animal Seizure and claims over land often happens between the palm oil investors with local society. One of them is the conflict between Air Abik society with PT. Gunung Pelawan Lestari.

The main factor of this conflict is there a logging, indigenous forest clearance, destruction of 11 ancestral graves belong to society conducted by PT. Gunung Pelawan Lestari in their efforts to oil palm expansions. This thing then triggered public protest action. survival. Whereas, ancestral grave is symbol of local wisdom and cultural heritage that must be preserved and maintained.

Besides, if we see the conflict between both sides, it can be analyzed with contentious politics theory. The use of contentious politics theory because this conflict involves the collective interaction between the claimant, i.e PT. Gunung Pelawan Lestari and claim object, i.e customary land and the land where the 11 ancestral graves stand. In contentious politics theory, there is also depletion of resources. This depletion of resources in the end will influencing people to get involved in the political tensions, like the high level of public complaints, legacy of previous protest, political opportunity structure, and the mechanism relation to help society resistance.
\end{abstract}

Keywords: agrarian conflicts, local society, palm oil investors.

\section{PENDAHULUAN}

\subsection{Latar Belakang}

Hadirnya era reformasi dengan uporia kebijakan otonomi daerahnya tentunya diharapkan mampu memberi kesempatan kepada pemerintah daerah Bangka Belitung (Babel) untuk memperoleh keuntungan dan meningkatkan kesejahteraan masyarakat dengan mendatangkan banyak investor melalui pemanfaatan sumber daya alam yang ada. Tidak hanya memanfaatkan bidang pertambangan timah, namun juga pemanfaatan bidang-bidang lain, salah satunya yang lagi men- jadi tren saat ini adalah dengan mendatangkan investor yang bergerak di perkebunan kelapa sawit. Hadirnya investor ini sangat jelas, memanfaatkan banyak lahan atau hutan untuk membuka perkebunan kelapa sawit. Namun ternyata, kebijakan yang semula didesain untuk mendapatkan pendapatan daerah dan bisa membuka banyak lapangan pekerjaan bagi masyarakatnya, justru malah menimbulkan masalah baru di Babel, yakni konflik agraria.

Ironis memang, di tengah semangat pemerintah daerah yang ingin mengembangkan dan 
memajukan Babel dengan mendatangkan banyak investor, namun kebijakan tersebut justru merugikan masyarakatnya sendiri, merampas hak-hak dan bahkan sampai merusak aset dan identitas masyarakat lokal yang ada di daerah tersebut. Salah satunya, seperti konflik yang terjadinya antara masyarakat dusun Air Abik, desa Gunung Muda, Kecamatan Belinyu, Kabupaten Bangka dengan PT. Gunung Pelawan Lestari. PT. Gunung Pelawan Lestari merupakan salah satu perusahaan yang bergerak dibidang perkebunan kelapa sawit di Babel.

Terjadinya konflik antara masyarakat dusun Air Abik dengan PT. GPL harus menjadi perhatian serius, baik oleh masyarakat maupun pemerintah daerah Babel. Menjadi perhatian serius karena semakin menambah daftar panjang konflik agraria di Babel. Kasus yang terjadi di Dusun Air Abik ini bukanlah satu-satunya konflik agraria yang terjadi antara masyarakat dan investor kelapa sawit di Babel. Sebelumnya pun sudah pernah terjadi kasus sama, sebut saja konflik terjadi di Desa Simpang Rimba dan Bangka Kota pada tahun 2008 lalu, serta konfik terjadi di Desa Ranggung Kecamatan Payung. Masih banyak konflik-konflik lain yang terjadi di beberapa wilayah di Babel antara masyarakat dan perusahaan kelapa sawit.

Sementara itu, kurangnya kesadaran masyarakat desa di Babel akan pentingnya pembuatan dan kepemilikan surat tanah, ditambah dengan keengganan masyarakat berurusan dengan birokrasi dalam pembuatan surat kepemilikan atas tanah menjadi faktor utama sering terjadinya konflik agraria di Babel. Hal ini ditambah lagi dengan tidak adanya sosialisasi-sosialisasi yang dilakukan oleh pemda mengenai reforma agraria kepada masyarakat desa. Sosialisasi mengenai reforma agraria (pembaruan agraria) menjadi penting artinya bagi masyarakat desa, karena reforma agraria hadir di tengah otonomi daerah melalui proses desentralisasi yang berorientasi pada kedaulatan dan kesejahteraan masyarakat. Selain itu, reforma agraria merupakan proses restrukturisasi (penataan ulang susunan) kepemilikan, penguasaan, dan penggunaan sumber-sumber agrarian (khususnya tanah).

Dengan tidak adanya sosialisasi-sosialisasi dilakukan, maka semakin banyak masyarakat yang kemudian enggan membuat surat tanah dan hanya berpatokan pada penjelasan batas-batas tanah dari orang tua terdahulu, atau hanya berpatokan pada bukti adanya tanaman "keras" yang ditanam di tanah tersebut. Semisal pohon durian, karet, petai, jengkol, pohon sengon, jati, dan lain-lain. Walaupun lahan atau tanahnya tidak diolah atau dibiarkan menjadi hutan, namun tanaman-tanaman tersebut dapat menjadi tanda atas kepemilikan seseorang akan tanahnya tersebut.

\subsection{Rumusan Masalah}

Berdasarkan latar belakang diatas, maka permasalahan penelitian ini dapat dirumuskan :

1. Bagaimana gerakan masyarakat dusun Air Abik menolak perluasan lahan perkebunan kelapa sawit ini berkembang?

2. Faktor apa saja yang menyebabkan gerakan ini berkembang?

\subsection{Tujuan Penelitian}

Penelitian ini bertujuan untuk mengetahui dan menganalisis gerakan serta faktor-faktor yang menyebabkan terjadinya perlawanan masyarakat dusun Air Abik dalam melakukan aksi penolakan perluasan lahan perkebunan sawit oleh PT. Gunung Pelawan Lestari.

\subsection{Metode Penelitian}

Jenis penelitian yang digunakan dalam penelitian ini adalah penelitian menggunakan teknik 
content analysis (analisis isi) dengan pendekatan kualitatif yang bersifat deskriptif. Hal ini bertujuan untuk menganalisis secara deskriptif mengenai perlawanan masyarakat dusun Air Abik terhadap kebijakan PT. Gunung Pelawan Lestari yang melakukan perluasan lahan perkebunan kelapa sawit yang dimuat dalam pemberitaan tribunnews.com tanggal 18 April 2014.

Sementara itu, content analysis sendiri merupakan analisis ilmiah tentang isi pesan suatau komunikasi dengan teknik discourse analysis yang cenderung pada pendalaman makna setiap berita yang disajikan kepada pembaca (Barcus dalam Muhadjir, 1996: 49).

\section{Pembahasan}

Kelapa sawit merupakan salah satu komoditas perkebunan yang sangat strategis. Maraknya penanaman kelapa sawit di Babel dimulai setelah berakhirnya era kejayaan komoditas lada, yakni sekitar tahun 1990-an. Di mana pada saat itu, kelapa sawit dengan cepat menjadi primadona bagi masyarakat di sektor perkebunan, selain dari sektor pertambangan timah. Bila melihat dari perkembangannya di negara kita, tentu perkebunan kelapa sawit sangat berkontribusi dalam membangun pertumbuhan perekonomian. Untuk itulah kemudia para kepala daerah di Indonesia, termasuk para kepala daerah di Babel terus memberikan surat izin kepada perusahaan kelapa sawit untuk membuka lahan perkebunan kelapa sawit.

Namun disamping itu, dinamika konflik sosial dan ekonomi dari perkebunan kelapa sawit dirasakan cukup tinggi. Pola hubungan yang kurang harmonis ini umumnya melibatkan masyarakat lokal, kelompok petani kelapa sawit mitra perusahaan dengan perusahaan kelapa sawit yang beroperasi di suatu daerah. Dan jika ditinjau dari intensitasnya, konflik terjadi ada yang bersi- fat laten, ada juga yang berbentuk konflik terbuka. Kasus yang bermula dari persoalan lahan ini adalah tipikal kasus konflik yang umum terjadi dalam perkebunan kelapa sawit di Indonesia. Hanya saja intensitas yang berbeda-beda.

Sementara pada konteks di Babel sendiri, Wahana Lingkungan Hidup (Walhi) Babel mencatat ada 13 konflik yang terjadi selama tahun 2011 terkait perkebunan sawit. Beberapa kasus terutama di Kabupaten Bangka seperti PT. BML di Gunung Muda, PT. Gunung Pelawan Lestari di Air Abik, Inhutani di Deniang-Air Hantu adalah sekelumit persoalan yang sampai saat ini belum usai. $^{1}$

\subsection{Analisis Kasus Melalui Teori Contentious Politics}

Teori contentious politics diajukan olen Mc Adam, Tarrow, dan Tilly. Teori ini untuk menjembatani kelemahan masing-masing teori dan konsep tentang gerakan sosial yang telah ada sebelumnya. Dengan contentious politics Tilly, McAdam, dan Tarrow maksudkan adalah peristiwa yang terjadi secara episodik atau tiba-tiba daripada reguler. Mereka juga mensyaratkan peristiwa melibatkan interaksi kolektif diantara pembuat klaim dan objek klaim ketika paling tidak satu pemerintah menjadi pengklaim atau objek klaim atau sebuah kelompok mengklaim dan bila terjadi akan mempengaruhi paling tidak salah satu objek yang di klaim. ${ }^{2}$

Artinya, penggunaan teori contentious politics dalam hal ini menjadi sangat relevan karena konflik yang terjadi melibatkan interaksi kolek-

1 Teddy Malaka, 2011. Walhi Babel: 2011 Ada 13 Titik Konflik Lahan Sawit. Melalui http://bangka.tribunnews.com/2011/12/31/walhi-babel-2011-ada-13konflik-lahan-sawit. Diakses Pada Tanggal 25 Juni 2014, Pukul 17:28 Wib.

2 Situmorang, 2013. Gerakan Sosial: Teori \& Praktik. Hlm 51-52. 
tif antara pengklaim, yakni PT. Gunung Pelawan Lestari dan objek klaim, yakni tanah adat dan lahan di mana terdapat 11 makam leluhur milik masyarakat dusun Air Abik, Desa Gunung Muda. Objek klaim tersebut akan menjadi perluasan lahan perkebunan kelapa sawit oleh PT. Gunung Pelawan Lestari. Karena adanya objek klaim yang berakibat pengerusakan hutan adat dan 11 makam leluhur inilah yang menyebabkan perlawanan masyarakat dusun Air Abik, Desa Gunung Muda. Dengan demikian, berdasarkan apa yang mereka maksud dengan contentious politics, sangat jelas bahwa Tilly, McAdam, dan Tarrow menekankan kasus-kasus ketegangan politik lintas sistem dan cara yang telah ada. Ini berarti di dalam peristiwa tersebut sejumlah aktor-aktor politik baru terlibat dan mempergunakan pendekatan baru sebagai alat politik. ${ }^{3}$

Selain itu, teori contentious politics juga menjadi variabel yang sangat relevan digunakan untuk menjelaskan gerakan perlawanan menentang perluasan lahan perkebunan kelapa sawit oleh PT. Gunung Pelawan Lestari. Menjadi relevan karena erat kaitannya denga penipisan sumberdaya. Menurut McCarthy dan Zald penipisan sumberdaya adalah salah satu contoh mekanisme lingkungan yang mempengaruhi orang terlibat di dalam ketegangan politik. ${ }^{4}$ Variabel dimaksud dalam konteks kasus ini, seperti tingginya tingkat keluhan masyarakat dusun Air Abik, Desa Gunung Muda, warisan aksi protes sebelumnya, struktur kesempatan politik, dan adanya mekanisme relasi dalam membantu perlawanan masyarakat.

\subsubsection{Tingkat Keluhan Masyarakat}

Variabel ini menjadi sangat aplikatif bila melihat perlawanan kelompok masyarakat da-

3 Situmorang, 2013. Gerakan Sosial: Teori \& Praktik. Hlm 52.

4 Situmorang, 2013. Gerakan Sosial: Teori \& Praktik. Hlm 53. lam menentang aktivitas perluasan lahan perkebunan kelapa sawit oleh oleh PT. Gunung Pelawan Lestari. Rujukan terpenting dalam variabel ini merujuk atas tingginya dampak negatif yang dirasakan oleh masyarakat dusun Air Abik dan masyarakat desa Gunung Muda, akibat dari aktivitas perluasan lahan untuk perkebunan kelapa sawit yang dilakukan oleh PT. Gunung Pelawan Lestari. Tingginya dampak negatif, yang ditimbulkan oleh aktivitas PT. Gunung Pelawan Lestari, yakni terjadinya pengerusakan dan penjarahan hutan adat desa, serta terjadinya pengerusakan 11 makam leluhur.

Atas terjadinya penjarahan, pengerusakan hutan adat desa, dan pengerusakan situs budaya, membuat masyarakat dusun Air Abik bersama dengan masyarakat desa Gunung Muda melaporkan kejadian tersebut kepada pihak kepolisian. Namun tidak ada tindakan lebih lanjut yang dilakukan oleh pihak kepolisian Polres Bangka.

"Perusakan makam leluhur ini sebetulnya telah kami laporkan ke Polres Bangka pada 5 Desember 2013 lalu. Namun, hingga kini, tidak ada kelanjutan. Polisi hanya memeriksa pelapor saja," kata Mat Jais, Kepala Dusun Air Abik.

Mat Jais mengatakan, hutan adat di daerah mereka sudah dijarah oleh pihak PT. Gunung Pelawan Lestari.

"Aparat hukum disana malah berpihak ke PT. GPL. Kami khawatir jika tidak diselesaikan, akan menimbulkan konflik seperti di Mesuji," ujarnya. ${ }^{5}$

Tidak hanya itu, beberapa perwakilan mas-

5 Wahyu Aji, 2014. Hutan dan Makan Leluhur Dirusak, Warga Minta Presiden SBY Turun Tangan. Melalui http://www.tribunnews.com/regional/2014/04/18/ hutan-dan-makam-leluhur-dirusak-warga-minta-presiden-sby-turun-tangan. Diakses Pada Tanggal 14 Juni 2014, Pukul 15:51 Wib. 
yarakat dusun Air Abik dan masyarakat desa Gunung Muda juga telah melaporkan kasus ini kepihak Mabes Polri dan Komnas HAM.

\subsubsection{Warisan Aksi Protes Sebelumnya}

Hadirnya variabel warisan aksi protes dalam analisis kasus ini menjadi penting artinya. Hal ini karena kasus yang terjadi antara masyarakat dusun Air Abik, Desa Gunung Muda dan PT. Gunung Pelawan Lestari sudah lama terjadi, yakni dimulai pada tahun 2011. Mengemukanya kembali kasus diantara kedua pihak tersebut pada tahun 2014 lalu merupakan kejadian lanjutan dari serangkaian aksi protes yang terjadi sebelumnya. Artinya bila melihat hal tersebut, mengindikasikan bahwa masyarakat yang menentang perluasan lahan perkebunan kelapa sawit ini telah terbiasa melakukan protes. Masyarakat dusun Air Abik, dibantu oleh masyarakat desa, perangkat-perangkat desa, dan tokoh pemuda yang melakukan aksi protes, tentunya telah belajar tentang bagaimana mengorganisasi dan mengelola massa dalam gerakan dan perlawanan mereka dalam menentang PT. Gunung Pelawan Lestari.

Adanya aksi demonstrasi yang dilakukan oleh masyarakat dusun Air Abik bersama dengan masyarakat desa Gunung Muda pada PT. Gunung Pelawan Lestari dan peerintah kabupaten Bangka menjadi contoh bahwa semenjak terjadinya konflik ini sejak tahun 2011, masyarakat bersama dengan aparat dusun dan desa kini telah terbiasa dalam mengorganisasi dan mengelola demonstrasi, juga menyusun, dan melaksanakan strategi dalam menyuarakan aspirasi mereka.

\subsubsection{Struktur Kesempatan Politik}

Munculnya gerakan aksi demonstrasi yang dilakukan oleh masyarakat dalam menentang perluasan lahan perkebunan kelapa sawit oleh PT. Gunung Pelawan Lestari dapat merujukkan kita pada variabel struktur politik. Struktur kesempatan politik tergantung pada perubahan struktur politik. Terjadinya perubahan struktur politik secara otomatis dapat menciptakan kesempatan muncul dan suksesnya dari gerakan perlawanan masyarakat.

Dalam konteks negara kita misalnya, hadirnya sistem demokrasi saat ini ditandai dengan lengsernya rezim otoritarianisme orde baru telah berhasil membuka kran kebangkitan, kebebasan, pemberian hak-hak sipil kepada seluruh masyarkat disegala lini kehidupan, dan semakin membuka keterbukaan informasi serta akuntabilitas publik. Hal ini karena demokrasi pada dasarnya adalah aturan orang (people rule), dan didalam sistem politik yang demokratis warga mempunyai hak, kesempatan dan suara yang sama di dalam mengatur pemerintahan di dunia publik. ${ }^{6}$

Dengan kata lain, hal tersebut mensyaratkan bahwa setiap warga negara mempunyai hak, kesempatan dan suara yang sama untuk menjadi agen kontrol (ceck and balance) kepada pemerintahan yang sedang berkuasa. Baik dilakukan dengan cara dialogis, demonstrasi yang damai maupun dengan cara-cara yang lain. Tidak hanya itu, kebebasan pers di era demokrasi inipun telah kembali semenjak terjadinya pembungkaman dan kontrol negara atas pers pada era orde baru. Untuk itulah, peran dan kedudukan media massa juga menjadi penting artinya dalam memberitakan berbagai kasus konflik agraria yang terjadi di Babel, termasuk pemberitaan terhadap kasus penjarahan dan pengerusakan hutan adat, serta perusakan 11 makan keramat milik masyaraat desa Air Abik, Desa Gunung Muda oleh pihak PT. Gunung Pelawan Lestari.

6 Wendy Melfa, 2013. Pemilukada (Demokrasi dan Otonomi Daerah). Hlm. 64-65. 


\subsubsection{Mekanisme Relasi (Relational Mecha- nisms)}

Secara umum, mekanisme merupakan sebuah kejadian yang mengubah hubungan di antara elemen-elemen tertentu dan cara-cara serupa. Sebuah contoh sentral tentang mekanisme relasional adalah brokerage (perantara), dimana dua unit sosial dibawa memasuki sesuatu hubungan dengan satu sama lain oleh unit ketiga. ${ }^{7}$ Mekanisme relasional kemudian mengubah hubungan antara orangorang, kelompok, dan jaringan interpersonal. Brokerage menghubungkan dua atau lebih situs sosial yang sebelumnya tidak terhubung oleh sebuah unit yang menengahi hubungan mereka dengan satu sama lain dan atau tanpaagen lain. Mekanisme berkaitan dengan kelompok dan individu satu sama lain yang termobilisasi selama periode politik perdebatan (contentious politics) sebagai kelompok baru yang disatukan oleh interaksi yang meningkat dan situasi ketidakpastian, sehingga menemukan kepentinganbersama mereka. ${ }^{8}$

Untuk itu, hadirnya gerakan perlawanan masyarakat dusun Air Abik, desa Gunung Muda terhadap PT. Gunung Pelawan Lestari tentunya juga tidak terlepas dari peran brokerage. Hadirnya brokerage dalam membantu gerakan perlawanan masyarakat tentunya akan semakin mensolidkan gerakan perlawanan. Dalam kasus ini, masyarakat dusun Air Abik, desa Gunung Muda dibantu oleh berbagai pihak, baik itu aparat pemerintah desa, tokoh-tokoh pemuda, maupun lembaga-lembaga swadaya masyarakat (LSM), seperti organisasi Dewan Pemuda Babel, Walhi Babel, Lembaga Bantuan Hukum (LBH) Bang$\mathrm{ka}$, dan peran media massa dalam memberitakan kasus yang terjadi ini.

Adanya peran serta masyarakat dan brokerage ini sejalan dengan teoritis gerakan-gera-

7 Van Klinken. 2007. Perang Kota Kecil. Hlm. 17

8 McAdam et.al. 2004. Dynamics of Contention. Hlm. 26. kan sosial yang mengemukakan bahwa adanya kerjasama antara agen dengan agen yang lebih berpengaruh, bersama-sama menggalang kekuatan dalam konfrontasi kolektif mereka melawan kelompok elit, pemegang otoritas dan musuh-musuh politik adalah bentuk paling modern dari politik perseteruan (contentious politics). ${ }^{9}$ Artinya, pola kerjasama inilah yang digunakan oleh masyarakat dusun Air Abik, desa Gunung Muda dalam melakukan perlawanan terhadap aktivitas yang dilakukan oleh PT. Gunung Pelawan Lestari tersebut. Di mana selain melibatkan lembaga desa, mereka juga melibatkan lembaga-lembaga independen seperti Dewan Pemuda Babel, Walhi Babel, LBH Bangka, dan media massa dalam memperjuangkan hutan adat dan 11 makam leluhur yang dikeramatkan. Hal ini dimaksudkan agar posisi tawar mereka menjadi kuat dalam hal menggiring wacana penyelamatan alam dan cagar budaya.

\subsection{Terancamnya Kelestarian Alam dan Rusaknya Sistem Kearifan Lokal Mas- yarakat}

Faktor utama yang melandasi terjadinya perlawanan masyarakat menentang perluasan lahan perkebunan kelapa sawit milik PT. Gunung Pelawan Lestari adalah terkait dengan kepemilikan dan kelestarian hutan adat yang telah lama terjaga dan terlestarikan. Tanpa ada pemberitahuan dan musyawarah kepada masyarakat, PT. Gunung Pelawan Lestari dengan tiba-tiba melakukan penebangan dan pembersihan hutan adat tersebut. Hal ini tentu saja memicu aksi protes masyarakat. Masyarakat menganggap PT. Gunung Pelawan Lestari telah melakukan penjarahan serta pengerusakan hutan adat desa.

9 Fauzi \& Mujani. 2009. Gerakan Kebebasan Sipil: Studi dan advokasi kritis atas Perda syari'ah. Hlm. 8; McAdam et.al. 2004. Dynamics of Contention. Hlm. 26. 
Padahal, melakukan pengerusakan hutan adat merupakan suatu tindakan melawan hukum. Hal ini karena adanya undang-undang yang mengatur tentang pengakuan dan perlindungan masyarakat adat berserta kepemilikan serta pengelolaan hutan adat. Seperti halnya UUD 1945, pasal 28 ayat 3 menyatakan bahwa identitas budaya dan hak masyarakat tradisional dihormati selaras dengan perkembangan zaman dan peradapan. Hal ini kemudian diperkuat melalui TAP MPR NO IX Tahun 2001 tentang Pembaruan Agraria dan Pengelolaan Sumber Daya Alam Pasal 5 huruf $\mathrm{j}$ yang menyatakan : Mengakui dan menghormati hak masyarakat hukum adat dan keragaman budaya bangsa atas sumber daya agraria dan sumber daya alam. Bahkan kini, negara pun tidak bisa mengklaim kepemilikannya atas hutan adat, setelah Mahkamah Konstitusi pada tanggal 16 Juni 2013 lalu mengabulkan sebagian judicial review UU Kehutanan No. 41 tahun 1999 tentang pokok-pokoh kehutanan yang diajukan Aliansi Masyarakat Adat Nusantara melalui putusannya No. 35 tahun 2012.

"Mengabulkan permohonan para pemohon untuk sebagian. Kata —negara dalam Pasal 1 angka 6 UU 41 tahun 1999 tentang Kehutanan bertentangan dengan UUD 1945," kata Akil Mochtar, Ketua MK saat membacakan amar putusan, sore itu. Dengan keputusan ini, kata 'negara'dalam Pasal 1 angka 6 itu tidak memiliki kekuatan hukum dan menjadi "Hutan adat adalah hutan yang berada dalam wilayah masyarakat hukum adat." 10

Artinya, Dengan keputusan Mahkamah

10 Sapariah Saturi, 2013. Mahkamah Konstitusi Putuskan Hutan Adat Bukan Hutan Negara. Melalui http:// www.mongabay.co.id/2013/05/16/mahkamah-konstitusi-putuskan-hutan-adat-bukan-hutan-negara/. Diakses Pada Tanggal 25 April 2015, Pukul 14:30 Wib.
Konstitusi tersebut, menegaskan hutan adat bukan hutan negara. Negara atau dalam hal ini adalah pemerintah daerah juga tidak bisa memberikan izin pengembangan dan pemanfaatan hutan adat kepada investor. Karena hutan adat merupakan identitas budaya dan merupakan simbol kelestarian alam serta tempat kelangsungan hidup hewan.

Sedangkan faktor kedua yang melandasi terjadinya perlawanan masyarakat ialah terjadinya pengerusakan terhadap 11 makam yang sangat dikeramatkan oleh masyarakat setempat. Hutan adat dan 11 makam leluhur inilah yang menjadi ciri khas dan kearifan lokal masyarakat dusun Air Abik. Makam leluhur merupakan simbol kearifan lokal masyarakat dan tergolong kedalam cagar budaya yang wajib untuk dijaga dan dipertahankan. Karena cagar budaya merupakan hasil kebudayaan manusia yang berupa benda-benda peninggalan masa lalu. Apalagi pada perkembangannya, hadirnya otonomi daerah sangat berpengaruh besar dalam hal pelestarian benda cagar budaya. Dimana hadirnya PP No. 25 Tahun 2000 tentang Kewenangan Pemerintah dan Kewenangan Provinsi Sebagai Daerah Otonom, maka PP No. 10 Tahun 1993 tentang Pelaksanaan UU No. 5 Tahun 1992 tentang Benda Cagar Budaya yang sudah tidak relevan lagi. Maka saat ini pelestarian benda cagar budaya telah menjadi kewenangan pemerintah provinsi yang selama ini dilakukan oleh pemerintah pusat. Untuk itulah, sudah menjadi tugas dan kewajiban Pemerintah Provinsi Kepulauan Bangka Belitung bersama dengan Pemerintah Kabupaten Bangka dalam upaya menjaga dan melesetarikan benda cagar budaya yang merupakan wujud jati diri kebudayaan bangsa kita.

Sementara itu, guna mempertahankan hutan dan dan 11 makam leluhur tersebutlah yang kemudian masyarakat dusun Air Abik bersama dengan 
masyarakat desa Gunung Muda melakukan aksi protes kepada PT. Gunung Pelawan Lestari. Aksi ini sampai pada terjadinya cekcok yang berakhir pada penangkapan masyarakat oleh kepolisian Polres Bangka. Adanya penangkapan dalam aksi protes ini, semakin membuat masyarakat kecewa, sebab aksi perluasan lahan perkebunan kelapa sawit oleh PT. Gunung Pelawan Lestari yang melakukan pengerusakan hutan adat dan 11 makam leluhur tidak ditindak tegas dan seolah dibiarkan oleh pihak kepolisian. Adanya kejadian semacam ini tentunya semakin menyebabkan terjadinya perlawanan masyarakat. Untuk itu kemudian perwakilan warga juga telah melaporkan ke Mabes Polri dan Komnas HAM terkait permasalahan tersebut. Perwakilan warga sendiri terdiri dari Mat Jais Kepala Dusun Air Abik, Syamsul Imran Kepala Desa Gunung Muda, Rusdi Ismunandar Ketua Badan Perwakilan Desa (BPD), Johan Tokoh pemuda, mengadukan aksi PT. Gunung Pelawan Lestari yang sudah dinilai melanggar serta perusakan lingkungan. ${ }^{11}$

Selain itu, pihak PT. Gunung Pelawan Lestari juga dianggap telah melakukan land clearing terhadap tanah milik masyarakat. Ade Putra Danishwara dari LBH Bangka yang mendampingi masyarakat menjelaskan,

"PT. Gunung Pelawan Lestari Melakukan kegiatan land clearing dan penanaman ditanah milik masyarakat tanpa kejelasan status GRTT (Ganti rugi terhadap tanah dan tanam tumbuh). Melakukan land clearing dan penanaman padahal belum mengantongi HGU, sehingga kuat dugaan PT. Gunung Pelawan Lestari melanggar UU Perkebu-

11 Wahyu Aji, 2014. Hutan dan Makan Leluhur Dirusak, Warga Minta Presiden SBY Turun Tangan. Melalui http://www.tribunnews.com/regional/2014/04/18/ hutan-dan-makam-leluhur-dirusak-warga-minta-presiden-sby-turun-tangan. Diakses Pada Tanggal 14 Juni 2014, Pukul 15:51 Wib. nan. PT. Gunung Pelawan Lestari melakukan Kegiatan penanaman di wilayah kawasan hutan HP maupun HL sehingga jelas melanggar UU Kehutanan." 12

\section{Penutup}

Konflik agraria yang terjadi di dusun Air Abik, desa Gunung Muda, dapat kita lihat berbagai keluhan masyarakat atas aktivitas perluasan lahan perkebunan kelapa sawit milik PT. Gunung Pelawan Lestari, adanya warisan aksi protes sebelumnya, terjadinya perubahan struktur politik pasca orde baru, dan adanya mekanisme relasional melalui brokerage, seperti LSM-LSM di Babel yang turut serta dalam mendukung dan membangun gerakan aksi bersama masyarakat. Hal ini tentunya berdampak pada semakin solidnya dan berkembangnya aksi perlawanan masyarakat dalam menentang perluasan lahan perkebunan kelapa sawit oleh PT. Gunung Pelawan Lestari.

Selain itu, rumit dan berlanjutnya kasus konflik diantara masyarakat dusun Air Abik tersebut tentunya semakin menambah daftar panjang konflik agraria yang ada di Babel. Seharusnya, konflik agraria yang banyak terjadi dibeberapa wilayah Indonesia sudah cukup menjadi pembelajaran dan contoh nyata bagi pemerintah daerah kita untuk mempertimbangkan pemberian izin lahan perkebunan kelapa sawit. Dalam pemberian izin lahan perkebunan kelapa sawit, hal yang diutamakan tentunya buka hanya pertimbangan keuntungan besar yang akan didapat dan seberapa besar keuntungan tersebut masuk ke kas daerah. Namun juga harus melihat pertimbangan dan dampak sosial yang terjadi dari pemberi-

12 Wahyu Aji, 2014. Hutan dan Makan Leluhur Dirusak, Warga Minta Presiden SBY Turun Tangan. Melalui http://www.tribunnews.com/regional/2014/04/18/ hutan-dan-makam-leluhur-dirusak-warga-minta-presiden-sby-turun-tangan. Diakses Pada Tanggal 14 Juni 2014, Pukul 15:51 Wib. 
an izin lahan perkebunan kelapa sawit tersebut. Pemerintah daerah, baik itu pemerintah provinsi atau pemerintah kabupaten, khususnya dalam hal ini adalah pemerintah kabupaten Bangka, harus tanggap dan turun tangan langsung untuk menyelesaikannya. Munculnya gerakan perlawanan masyarakat menentang perluasan lahan perkebunan kelapa sawit ini sendiri merupakan suatu tindakan kekecewaan masyarakat karena kurangnya peran pemerintah kabupaten Bangka sebagai pihak yang mengeluarkan surat izin, dalam menyelesaikan konflik yang terjadi.

Oleh karenanya, untuk mencegah terjadinya konflik semacam ini, sudah saatnya pemerintah daerah mengutamakan konsep investasi dan pembangunan yang lebih pro terhadap lingkungan, yakni kebijakan yang tetap menjaga kelesatrian dan kehijauan hutan, serta menjaga dan merawat cagar-cagar budaya sebagai bentuk kearifan lokal masyarakat. Selain itu, sudah saatnya pula mengkonsepsikan investasi yang ramah masyarakat, yakni mengharai hak-hak, identitas, dan kearifan lokal masyarakat. Hal ini penting dilakukan guna mencegah konflik diantara masyarakat dengan pihak perusahaan perkebunan kelapa sawit.

\section{DAFTAR PUSTAKA}

\section{Sumber Buku :}

Ali-Fauzi, Ihsan \& Saiful Mujani (eds), 2009. Gerakan Kebebasan Sipil: Studi dan advokasi kritis atas Perda syari'ah. Jakarta: Nalar dan Freedom Institute.

Klinken, Gerry Van, 2007. Perang Kota Kecil.Jakarta: KITLV-Yayasan Obor Indonesia.

McAdam, Doug, Sidney Tarrow \& Charles Tilly, 2004. Dynamics of Contention. Cambridge: Cambridge University Press.

Melfa, Wendy, 2013. Pemilukada (Demkrasi dan Otonomi Daerah). Lampung: BE Press.

Muhadjir, Noeng, 1996. Metode Penelitian Kualitatif Edisi III, Yogyakarta: PT. Bayu Indra Grafika.

Situmorang, Abdul Wahib, 2013. Gerakan Sosial: Teori \& Praktek. Yogyakarta: Pustaka Pelajar.

\section{Sumber Internet :}

Aji, Wahyu, 2014. Hutan dan Makan Leluhur Dirusak, Warga Minta Presiden SBY Turun Tangan. Melalui http://www.tribunnews.com/regional/2014/04/18/hutan-danmakam-leluhur-dirusak-warga-minta-presiden-sby-turun-tangan. Diakses Pada Tanggal 14 Juni 2014, Pukul 15:51 Wib.

Malaka, Teddy, 2011. Walhi Babel: 2011 Ada 13 Titik Konflik Lahan Sawit. Melalui http:// bangka.tribunnews.com/2011/12/31/walhi-babel-2011-ada-13-konflik-lahan-sawit. Diakses Pada Tanggal 25 Juni 2014, Pukul 17:28 Wib.

Saturi, Sapariah, 2013. Mahkamah Konstitusi Putuskan Hutan Adat Bukan Hutan Negara. Melalui http://www.mongabay.co.id/2013/05/16/mahkamah-konstitusi-putuskan-hutan-adat-bukan-hutan-negara/. Diakses Pada Tanggal 25 April 2015, Pukul 14:30 Wib. 